\title{
Administration of oral anticoagulants in periprocedural complications based on case report series
}

\author{
Stosowanie doustnych leków przeciwkrzepliwych w powikłaniach okołozabiegowych \\ na podstawie serii przypadków klinicznych
}

\author{
Agata Tymińska, Krzysztof Ozierański, Paweł Balsam, Michał Peller, Piotr Lodziński, \\ Marcin Grabowski, Grzegorz Opolski
}

$1^{\text {st }}$ Department of Cardiology, Medical University of Warsaw, Warsaw, Poland

\begin{abstract}
The use of dabigatran, a non-vitamin $\mathrm{K}$ antagonist (VKA) oral anticoagulant, is still increasing. Dabigatran has a good efficacy and safety ratio, as well as a more predictable anticoagulation effect compared with VKA. On the other hand, there is acenocoumarol/warfarin, a VKA which was evaluated in numerous clinical trials and is a drug of choice in a valve-related atrial fibrillation (AF).

Based on the real clinical cases, we attempted to summarize current recommendations on how to manage periprocedural complications on oral anticoagulant treatment.

In the first case we presented a patient on dabigatran, undergoing pulmonary vein isolation (PVI) of AF, who developed a right groin hematoma after the procedure and hence required several blood transfusions. In the second case we showed a patient on acenocoumarol, with high bleeding risk, who developed a pocket hematoma after an implantable cardioverter-defibrillator (ICD) implantation. We also reported a patient on dabigatran, who developed a femoral artery pseudoaneurysm (FAP) following PVI of AF.

Periprocedural oral anticoagulation depends on the anticoagulant type and requires individual assessment of the patient's thromboembolic and bleeding risk factors. Our case reports showed that in case of a bleeding, dabigatran may be quickly stopped and then restarted recently after reaching hemostasis, in contrast to acenocoumarol. They also confirm a possibility of successful pseudoaneurysm closure without dabigatran suspension.
\end{abstract}

Key words: acenocoumarol, dabigatran, hematoma, periprocedural complications, pulmonary vein isolation, implantable cardioverter-defibrillator, pseudoaneurysm

Folia Cardiologica 2016; 11, 5: 455-461

\section{Introduction}

Oral anticoagulant therapy is commonly used in an everyday practice. However, clinicians have to deal with a thrombotic and bleeding risk, which frequently is problematic, especially in patients requiring invasive treatment. Currently no evidence-based guidelines are available for periprocedural complications in anticoagulated patients. Pulmonary vein isolation (PVI) of atrial fibrillation (AF) and implantation of cardiac rhythm devices are associated with a 1-2\% risk of serious bleedings (tamponade, hemothorax) and $5 \%$ of minor bleedings (groin bleedings, hematomas). However, incidence of those complications is decreasing in recent trials [1]. 

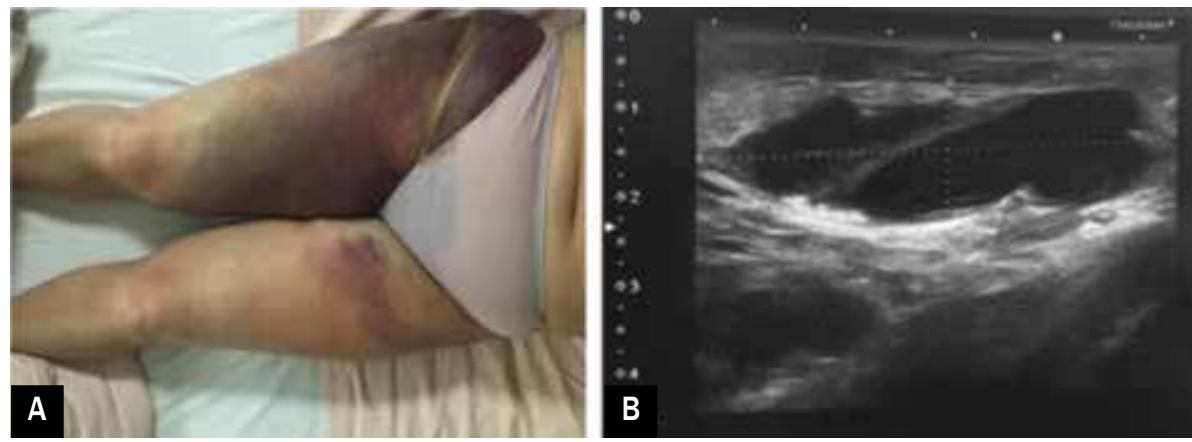

Figure 1A. Anteroposterior view of a large groin hematoma after pulmonary vein isolation in a patient with atrial fibrillation; $B$. Ultrasound sonography shows dimensions of the intramuscular hematoma

Dabigatran, as a non-vitamin $\mathrm{K}$ antagonist (VKA) oral anticoagulant (NOAC), is a treatment of choice for thrombo-embolic prevention in patients with a non-valvular AF [1]. The aim of this paper was to summarize the principles of management of periprocedural complications, during different oral anticoagulant treatment. We presented two cases of patients using dabigatran (treated with $\mathrm{PVI}$ ) and one case of a patient using acenocoumarol after ICD implantation.

\section{Case details}

\section{Case 1}

A 64-year-old female with persistent AF was admitted for PVI. Medical history included arterial hypertension and obesity, with normal renal and liver function. The patient was assessed on 2 points in $\mathrm{CHA}_{2} \mathrm{DS}_{2} \mathrm{VASc}$ score and on 1 point in HAS-BLED score. AF, lasting from about 3 years, was symptomatic (EHRA III, European Heart Rhythm Association). Before admission, the patient was receiving perindopril, bisoprolol, spironolactone, propafenone and dabigatran (150 mg bid). On presentation, her vitals were: blood pressure (BP) 140/90 mm Hg, pulse was irregulararound $90 \mathrm{bpm}$. Clotting times were normal. On the second day of the hospitalization the patient underwent a PVI and was admitted in a good general condition to intensive cardiac care unit for monitoring. After eight hours of the pressure bandage observation, hematoma appeared in the right groin (Figure 1A). Cardiovascular examination showed signs of a hemorrhagic shock: tachycardia - $100 \mathrm{bpm}$, BP 100/60 mm Hg. Laboratory findings were: red blood cells $(\mathrm{RBC})-2.82 \times 10^{6} / \mu \mathrm{l}$ (baseline: $4.22 \times 10^{6} / \mu \mathrm{l}$ ) and hemoglobin $-8.3 \mathrm{~g} / \mathrm{dl}$ (baseline: $12.7 \mathrm{~g} / \mathrm{dl}$ ). At that time the patient received aggressive IV fluid replacement. In the following few hours, further decrease of blood parameters was observed: RBC $-2.34 \times 10^{6} / \mu \mathrm{l}$, hemoglobin $-7.2 \mathrm{~g} / \mathrm{dl}$ and hematocrit $-21.1 \%$. Group and cross-match was taken. The patient was transfused one unit of packed RBC (PRBC), with poor outcome and in the next day another two units, reaching $\mathrm{RBC}-3.2 \times 10^{6} / \mu \mathrm{l}$ and hemoglobin $10.0 \mathrm{~g} / \mathrm{dl}$. Her BP improved to $132 / 69 \mathrm{~mm} \mathrm{Hg}$ and pulse to $85 \mathrm{bpm}$.
Large intramuscular hematoma with three compartments (the largest was $64 \times 20 \times 54 \mathrm{~mm}$ ) (Figure 1B) was revealed in USG of the right groin. It was concluded that the bleeding was likely an adverse effect of a daily dabigatran therapy. Dabigatran was continued through the hospitalization except the ablation day. During further hospitalization a control USG study confirmed hematoma absorption and the patient was discharged in a good general condition.

\section{Case 2}

A 79-year-old man with dilated cardiomyopathy and severe heart failure was readmitted 14 days after implantation ( 9 days after discharge) of a single-chamber cardioverter-defibrillator (ICD) with a pocket hematoma. Relevant medical history included: chronic acenocoumarol treatment due to persistent AF, chronic kidney disease stage G3b, post-thrombotic syndrome and percutaneous mitral valve repair with MitraClip. Before admission, the patient received furosemide, ramipril, carvedilol, eplerenone, allopurinol and acenocoumarol (4 mg OD). On presentation, large hematoma with a superficial bruise on the anterior chest was seen (Figure 2A). The patient did not suffer from chest pain or shortness of breath. His vitals were: BP 93/62 mm Hg and irregular pulse - around 75 bpm. Laboratory findings were: hemoglobin $-10.7 \mathrm{~g} / \mathrm{dl}$ (last known: $11.24 \mathrm{~g} / \mathrm{dl}$ ), platelets $-253 \times 10^{3} / \mu \mathrm{l}$ (normal range $150-400 \times 10^{3} / \mu \mathrm{l}$ ), creatinine $-1.52 \mathrm{mg} / \mathrm{dl}$, INR 2.21, prolonged APTT $-52.9 \mathrm{~s}$. USG of the chest revealed a large pocket hematoma with dimensions $42 \times 48 \times 8 \mathrm{~mm}$ (Figure 2B). Firstly, a sterile compression therapy was applied. It was concluded that hematoma was likely an adverse effect of acenocoumarol, which was wherefore suspended and replaced by enoxaparine ( $80 \mathrm{mg}$ od) after one day cessation of the anticoagulation therapy. On consecutive day the hematoma was evacuated. After 2 weeks of the further hospitalization the hematoma absorption was observed and acenocoumarol was then gradually restarted with a low dose (2 mg). The patient was discharged in a good general condition, with the recommendations of INR level check every 2-3 weeks. 

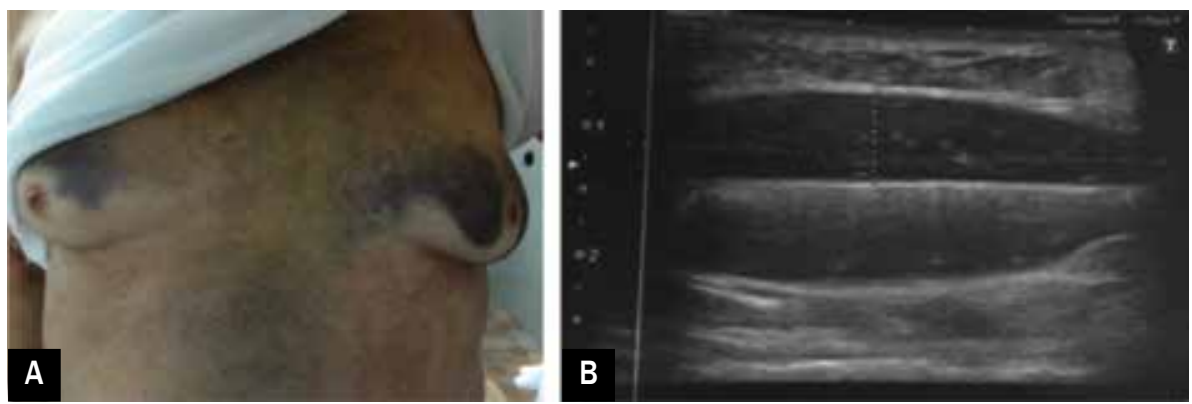

Figure 2A. Anteroposterior view of a chest bruise in a patient who underwent a device implantation; B. Ultrasound sonography shows dimensions of the pocket hematoma
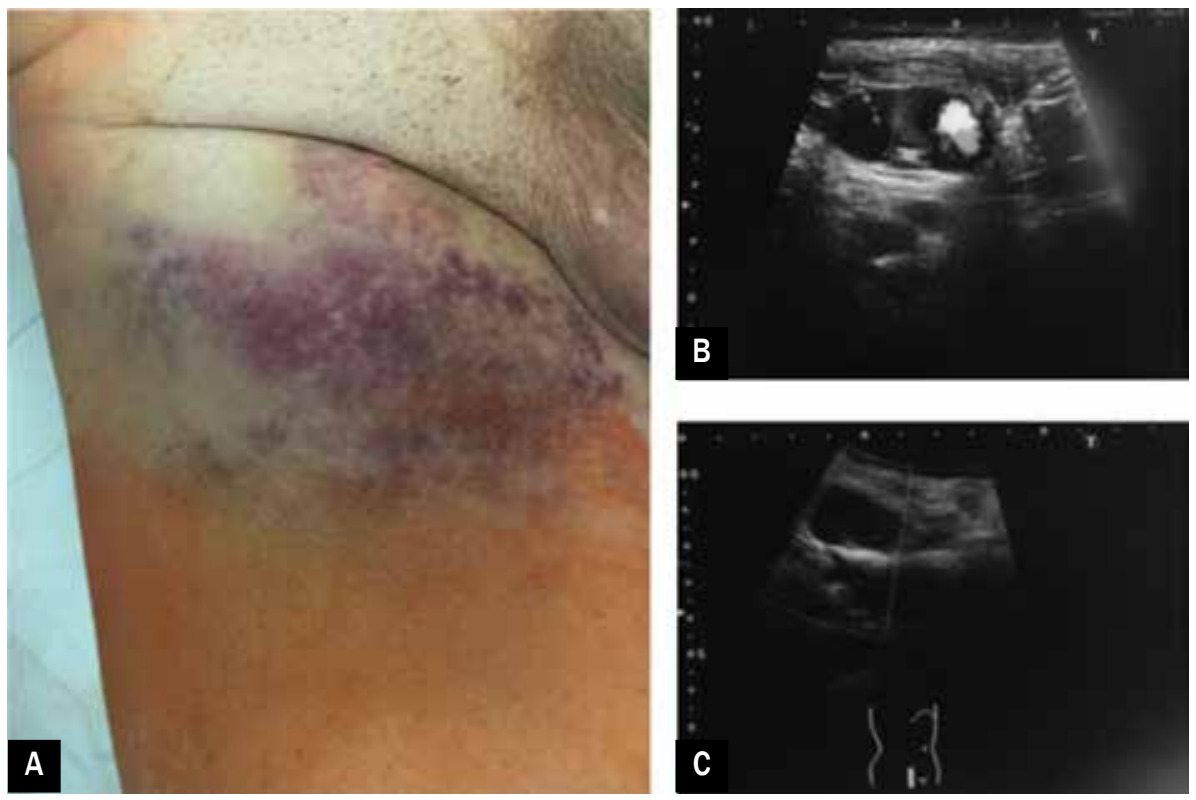

Figure 3A. Anteroposterior view of a skin bruise of the right groin in a patient who underwent pulmonary vein isolation; B, C. Ultrasound sonography view of the pseudoaneurysm

\section{Case 3}

A 66-year-old man, with a paroxysmal AF and atrial flutter was admitted to the hospital for a transcutaneous radiofrequency ablation of the arrhythmia. The symptoms were assessed as EHRA III. Medical history included stable coronary artery disease, arterial hypertension, diabetes mellitus type 2, hyperthyroidism, and hyperlipidemia. Renal and liver function were normal. The patient was assessed on 3 points in $\mathrm{CHA}_{2} \mathrm{DS}_{2} \mathrm{VASc}$ score and on 2 points in HAS-BLED score. The patient before admission was receiving valsartan, metoprolol, metformin, gliclazide, dabigatran $(150 \mathrm{mg}$ bid, it was continued through the hospitalization except the ablation day). On presentation, his vitals were: BP 135/70 mm Hg, pulse was irregular - around $72 \mathrm{bpm}$. Next day after ablation, after removal of the pressure dressing, skin bruise was presented (Figure 3A). Furthermore murmur and severe pain in the right groin was found. Control US study revealed a femoral artery pseudoaneuysm (FAP) $(38 \times 30 \times 15 \mathrm{~mm})$
(Figure 3B). Consulting vascular surgeon applied a percutaneous injection of thrombin into the pseudoaneurysm cavity, without dabigatran suspension. Clotting of the pseudoaneurysm was obtained. The patient was discharged 3 days after ablation without any complications.

\section{Discussion}

High dose (150 mg bid) of dabigatran has an improved efficacy and comparable safety ratio, does not require routine monitoring because of a predictable effect, fewer food and drug interactions, compared with VKA [1], as presented in Table 1. Dabigatran and warfarin (which was used in most of the clinical trials comparing VKA drugs, but it has similar characteristics to acenocoumarol) have similar numbers of thrombo-embolic and bleeding events in patients undergoing PVI of AF and implantation of cardiac rhythm devices $[2,3]$. Consensus statement recommended uninterrupted 
Table 1. Pharmacokinetic differences between dabigatran etexilate and acenocoumarol (based on the antithrombotic guidelines of the American College of Chest Physicians [ACCP] [9])

\begin{tabular}{|c|c|c|}
\hline Parameter & Dabigatran & Acenocoumarol \\
\hline $\begin{array}{l}\text { Mechanism - site of actions in the coa- } \\
\text { gulation cascade }\end{array}$ & Direct inhibitor of factor II (thrombin) & $\begin{array}{l}\text { Reduced synthesis of coagulation factors } \\
\text { vitamin K-dependent (II, VII, IX, X, protein C } \\
\text { and protein S) }\end{array}$ \\
\hline Half-live [h] & $12-14$ & $8-11$ \\
\hline Bioavailability [\%] & $\sim 6$ & $>60$ \\
\hline $\begin{array}{l}\text { Time to reach maximum serum concen- } \\
\text { trations }[\mathrm{h}]\end{array}$ & $0.5-2$ & $36-48 *$ \\
\hline Dose & $2 \times /$ day, fixed dosing** & $\begin{array}{l}1 \times / \text { day, dosage maintenance established } \\
\text { with INR monitoring }\end{array}$ \\
\hline $\begin{array}{l}\text { Clearance non-renal/renal of absorbed } \\
\text { dose (normal renal function) [\%] }\end{array}$ & $20 / 80$ & $30 / 60$ \\
\hline Plasma protein binding [\%] & 35 & 99 \\
\hline Metabolism by cytochrome P450 & No & Yes (mainly CYP2C9) \\
\hline Interactions with drugs and food & Low potential for interactions & Variety mechanisms of interaction \\
\hline Antidote & $\begin{array}{l}\text { Humanized monoclonal antibody frag- } \\
\text { ment (Fab) - idarucizumab }\end{array}$ & $\begin{array}{l}\text { Fast reversal effect using PCC or FFP, slow } \\
\text { reversal onset using vitamin K }\end{array}$ \\
\hline
\end{tabular}

Table 2. Patients undergoing a planned surgical intervention or ablation: when to stop dabigatran therapy? (based on European Heart Rhythm Association [EHRA] Practical Guide [1])

$\begin{array}{lcc}\begin{array}{l}\text { Creatinine clearance } \\ {[\mathrm{mL} / \mathrm{min}]}\end{array} & \text { Low risk }[\mathrm{h}] & \text { High risk [h] } \\ \geq 80 & \geq 24 & \geq 48 \\ 50-80 & \geq 36 & \geq 72 \\ 30-50 & \geq 48 & \geq 96 \\ <30 & \text { Not indicated } & \text { Not indicated }\end{array}$

When there is no major bleeding risk and normal creatinine clearance performed $\geq 12$ or $24 \mathrm{~h}$ after last intake of dabigatran

There is no need for bridging with LMWH/UFH when dabigatran is used

Bleeding risk factors: patient's age ( $\geq 75$ years), renal and liver dysfunction, weight ( $\leq 60 \mathrm{~kg}$ ), drug interactions (antiplatelets; NSAIDs; systemic steroid therapy; other anticoagulants), history of Gl bleeding, thrombocytopenia (e.g. chemotherapy), HAS-BLED $\geq 3$, recent surgery on critical organ (brain, eye)

LMWH - low molecular weight heparin; UFH - unfractionated heparin; NSAIDs - nonsteroidal anti-inflammatory drugs; Gl - gastrointestinal

VKA treatment (with target INR 2.0-2.5) performing PVI because of lower rate of thrombo-embolic and bleeding events (compared with interrupted treatment) [4]. Recently dabigatran demonstrated similar safety to warfarin, giving the opportunity for continuous proceeding with OAC [4], but still it is recommended to stop dabigatran $\geq 24 \mathrm{~h}$ prior to a procedure.

In the $1^{\text {st }}$ case, there was presented intramuscular bleeding after right femoral vein puncture for PVI. A bleeding risk of our patient was assessed as low and according to the recommendations, dabigatran was stopped $24 \mathrm{~h}$ before the PVI (Table 2) [1]. It is suggested that the activated partial thromboplastin time (APTT) independently predict periprocedural complications in the dabigatran group [5]; however, clotting times of our patient before procedure were normal and after were unknown. During the ablation, the active clotting time (ACT) test is used because of high heparin doses and that APTT is too sensitive [1]. ACT should achieve 300-350 s in NOAC- or VKA-treated patients [1]. Dabigatran can be restarted 3-4 $\mathrm{h}$ after sheath removal in patients with an adequate hemostasis and the absence of a pericardial effusion [1]. Maximal anticoagulation effect is achieved within $2 \mathrm{~h}$ of ingestion [1]. Despite a low bleeding risk, our patient had a major bleeding (hemoglobin dropped to $7.2 \mathrm{~g} / \mathrm{dl}$ ) requiring transfusion of 3 PRBC units (proceedings in dabigatran-related bleedings are 


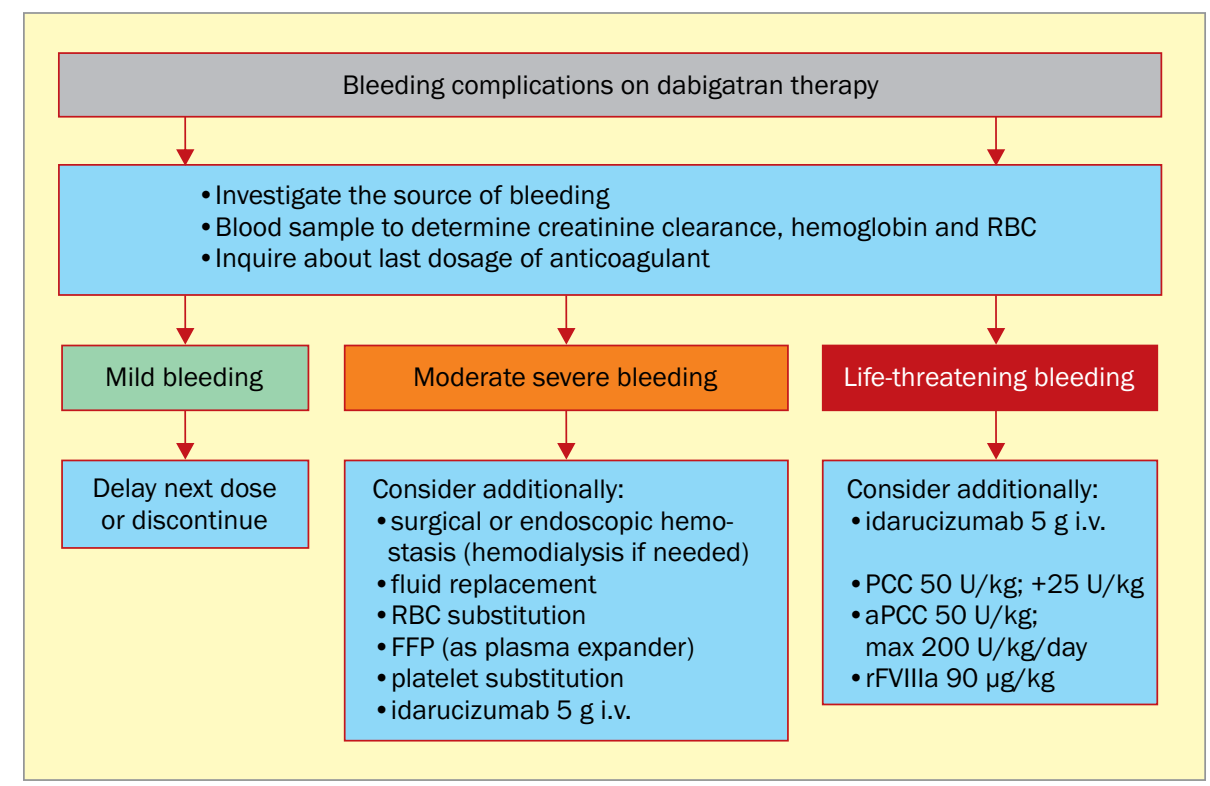

Figure 4. Possible management of bleeding complications on dabigatran therapy (based on European Heart Rhythm Association [EHRA] [1]); RBC - red blood cells; FFP - fresh frozen plasma; i.v. - intravenous; aPCC - activated prothrombin complex concentrate; rFVIla recombinant factor VIla

Table 3. Patients undergoing a planned surgical intervention or ablation: when to stop vitamin-K antagonists (VKA) therapy? (based on the antithrombotic guidelines of the American College of Chest Physicians [ACCP] [10])

\begin{tabular}{|c|c|}
\hline The risk for thrombo-embolism & Vitamin-K antagonists \\
\hline \multirow[t]{3}{*}{ Low } & Discontinue drug for up to $48 \mathrm{~h}$ (to obtain normal INR) \\
\hline & If despite the discontinuation of VKA INR is still $\geq 1.5$ \\
\hline & 1-2 days before surgery $\rightarrow$ administrate p.o. $1-2 \mathrm{mg}$ of vitamin $\mathrm{K} 1$ \\
\hline High & Additionally, need for bridging with LMWH/UFH \\
\hline \multicolumn{2}{|c|}{$\begin{array}{l}\text { Bleeding risk factors: INR > } 5 \text { (significant increase in risk), patient's age ( }>65 \text { years), history of Gl bleeding, concomitant diseases } \\
\text { (cancer, renal and liver disease, uncompensated hypertension, ischemic stroke, alcoholism), drug interactions (antiplatelets, NSAIDs), } \\
\text { thrombocytopenia }\end{array}$} \\
\hline
\end{tabular}

shown in Figure 4). From recent idarucizumab approval, there is a possibility of rapid reverse of the dabigatran anticoagulant action, in case of a need for an emergent surgery or a life-threatening bleeding [1]. However, at that time idarucizumab was still unavailable in our hospital and probably it would not change the prognosis of the patient. Dabigatran was continued since next day after ablation when hemoglobin concentration stabilized.

A pocket hematoma is an acute complication after a device implantation [6]. It occurs in $2-4 \%$ of cases, but the risk is increased in anticoagulated patients (up to $12-23 \%$ ) [6]. The $2^{\text {nd }}$ case presented a patient with a pocket hematoma developed over few days after ICD implantation. This patient required an adequate anticoagulation because of a valvular-AF and a post-thrombotic syndrome. However, he had also an increased risk of a VKA-related bleeding due to advanced age, severe heart and renal failure. His
INR level was appropriate (2.21) but he had prolonged APTT (52.9 s). In consequence, the bleeding exacerbated anemia and acenocoumarol was suspended (proceedings in planned procedures and bleedings on acenocoumarol treatment are shown in Table 3 and Figure 5, respectively). Because of a considerable size of hematoma, our patient required a surgical intervention. Based on the literature, surgical hematoma evacuation is required in 1-2\% [6]. Pocket hematoma related to device implantation is also associated with an increased risk of infection and often leads to prolonged hospital stays [6].

The $3^{\text {rd }}$ case presented a FAP in the right groin of a patient who underwent transcutaneous radiofrequency ablation. A FAP is one of the most undesirable complications after invasive procedures and its incidence is still increasing [7]. A FAP is associated with anticoagulation and there is a need for further research on the use of 


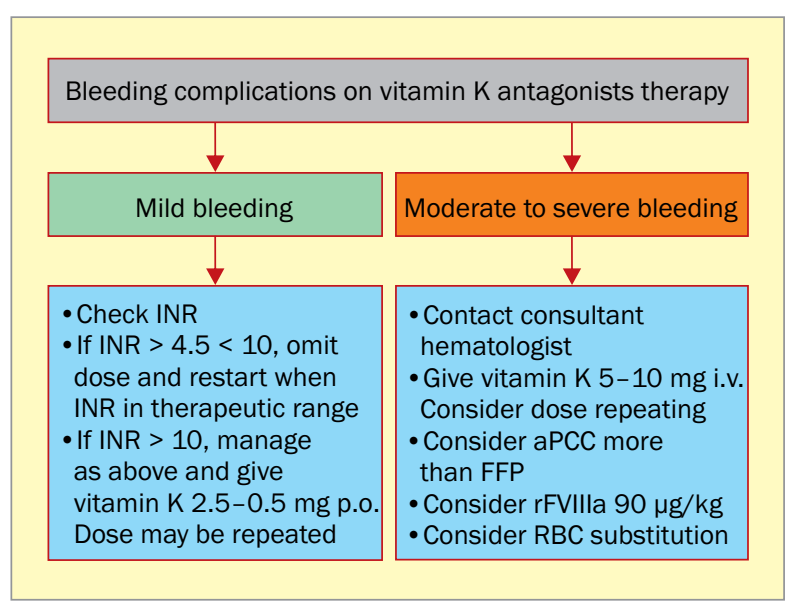

Figure 5. Possible management of bleeding complications on acenocoumarol therapy (based on the antithrombotic guidelines of the ACCP [10]); INR - international normalized ratio; p.o. - per os; i.v. - intravenous; aPCC - activated prothrombin complex concentrate; FFP - fresh frozen plasma; rFVIla - recombinant factor VIla; $\mathrm{RBC}$ - red blood cells

dabigatran in patients with a FAP [7]. In our patient a FAP appeared on the next day after ablation. The probability of a spontaneous FAP closure remarkably decreases in patients on anticoagulation and it usually needs a thrombin injection [7]. Conservative treatment can be used in not anticoagulated patients with small $(<2 \mathrm{~cm})$ and asymptomatic pseudo-aneurysms [7]. FAP due to a severe pain and large dimensions $(>3 \mathrm{~cm}$, which is a significant risk of a pseudoaneurysm rupture [7]) required an intervention. In patients with normal creatinine clearance and with a low risk of bleeding, interventions can be performed 12-24 $\mathrm{h}$ after the last dabigatran intake (Table 2) [1]. However, our case confirms a possibility of a successful pseudoaneurysm closure without dabigatran suspension, which is consistent with Dzijan-Horn et al. recommendations [8].

\section{Conclusions}

Periprocedural oral anticoagulation depends on the anticoagulant type and requires individual assessment of the patient's thromboembolic and bleeding risk factors. Our study shows that in case of a bleeding, dabigatran may be quickly stopped and then restarted recently after reaching hemostasis, in contrast to acenocoumarol. It also confirms a possibility of a successful pseudoaneurysm closure without dabigatran suspension.

\section{Conflict of interest(s)}

None declared.

\section{Cotribution statement}

$\mathrm{PB}$ and $\mathrm{MG}$ conceived the idea for the study. AT and $\mathrm{KO}$ researched data. AT, KO, PB, MP, PL and MG, GO designed the analysis, conducted data interpretation and wrote the manuscript. All authors edited and approved the final version of the manuscript.

\section{Streszczenie}

Zastosowanie dabigatranu, doustnego antykoagulantu niebędącego antagonistą witaminy $\mathrm{K}$, jest coraz powszechniejsze. Z jednej strony dabigatran cechuje się dobrą skutecznością i bezpieczeństwem, a także bardziej przewidywalnym działaniem przeciwzakrzepowym niż antagoniści witaminy K. Z drugiej strony jest acenokumarol/warfaryna, antagonista witaminy K, który oceniano w wielu badaniach klinicznych - lek z wyboru w zastawkowym migotaniu przedsionków.

Na podstawie przypadków klinicznych autorzy starali się podsumować aktualne zalecenia postępowania w przypadku okołozabiegowych powikłań podczas doustnego leczenia przeciwkrzepliwego. W 1. przypadku zaprezentowali pacjenta stosującego dabigatran, poddanego izolacji żył płucnych, u którego po zabiegu wystąpił krwiak prawej pachwiny i w konsekwencji chory wymagał kilku transfuzji krwi. W 2. przypadku opisali pacjenta stosującego acenokumarol, z wysokim ryzykiem krwawienia, u którego pojawił się krwiak loży pooperacyjnej po implantacji kardiowertera-defibrylatora. Przedstawiono również pacjenta poddanego terapii dabigatranem, u którego wystąpił tętniak rzekomy prawej tętnicy udowej po zabiegu izolacji żył płucnych.

Okołozabiegowa doustna antykoagulacja zależy od rodzaju antykoagulantu oraz wymaga indywidualnej weryfikacji czynników ryzyka krwawienia i prozakrzepowych u danego pacjenta. Opisy tych przypadków pokazały, że jeśli wystąpi krwawienie, to dabigatran można szybko odstawić i ponownie włączyć niedługo po osiągnięciu hemostazy, w przeciwieństwie do acenokumarolu. Potwierdzają one również możliwość pomyślnego zamknięcia tętniaka rzekomego bez odstawiania dabigatranu.

Słowa kluczowe: acenokumarol, dabigatran, krwiak, komplikacje okołozabiegowe, izolacja żył płucnych, wszczepialny kardiowerter-defibrylator, tętniak rzekomy

Folia Cardiologica 2016; 11, 5: 455-461 


\section{References}

1. Heidbuchel H, Verhamme P, Alings $M$ et al. Updated European Heart Rhythm Association Practical Guide on the use of non-vitamin K antagonist anticoagulants in patients with non-valvular atrial fibrillation. Europace 2015; 17: 1467-1507.

2. Providencia R, Albenque JP, Combes $\mathrm{S}$ et al. Safety and efficacy of dabigatran versus warfarin in patients undergoing catheter ablation of atrial fibrillation: a systematic review and meta-analysis. Heart 2014; 100: 324-335.

3. Rowley CP, Bernard ML, Brabham WW et al. Safety of continuous anticoagulation with dabigatran during implantation of cardiac rhythm devices. Am J Cardiol. 2013; 111: 1165-1168.

4. Calkins H, Kuck KH, Cappato R et al. 2012 HRS/ EHRA/ECAS expert consensus statement on catheter and surgical ablation of atrial fibrillation: recommendations for patient selection, procedural techniques, patient management and follow-up, definitions, endpoints, and research trial design. EP Europace 2012; 14: 528-606.

5. Nagao $T$, Inden $Y$, Shimano $M$ et al. Feasibility and safety of uninterrupted dabigatran therapy in patients undergoing ablation for atrial fibrillation. Intern. Med. 2015; 54: 1167-1173.
6. Kutinsky IB, Jarandilla R, Jewett M, Haines DE. Risk of hematoma complications after device implant in the clopidogrel era. Circ Arrhythm Electrophysiol. 2010; 3: 312-318.

7. Badr S, Kitabata H, Torguson R et al. Incidence and correlates in the development of iatrogenic femoral pseudoaneurysm after percutaneous coronary interventions. J Interv Cardiol. 2014; 27: 212-216.

8. Dzijan-Horn M, Langwieser N, Groha P et al. Safety and efficacy of a potential treatment algorithm by using manual compression repair and ultrasound-guided thrombin injection for the management of iatrogenic femoral artery pseudoaneurysm in a large patient cohort. Circ Cardiovasc Interv. 2014; 7: 207-215.

9. Ansell J, Hirsh J, Hylek E et al. American College of Chest Physicians: Pharmacology and management of the vitamin $\mathrm{K}$ antagonists: American College of Chest Physicians evidence-based clinical practice guidelines (8th ed.). Chest 2008; 133 (6 Suppl): 160S-198S.

10. Douketis JD, Spyropoulos AC, Spencer FA, at al. Perioperative Management of Antithrombotic Therapy and Prevention of Thrombosis (9th ed.). American College of Chest Physicians evidence-based clinical practice guidelines. Chest 2012; 141 (2 Suppl): 326S-350S. 